\title{
Peripheral intracranial aneurysm causing subdural hematoma without subarachnoid hemorrhage
}

Figure $1 \quad$ Brain neuroimaging
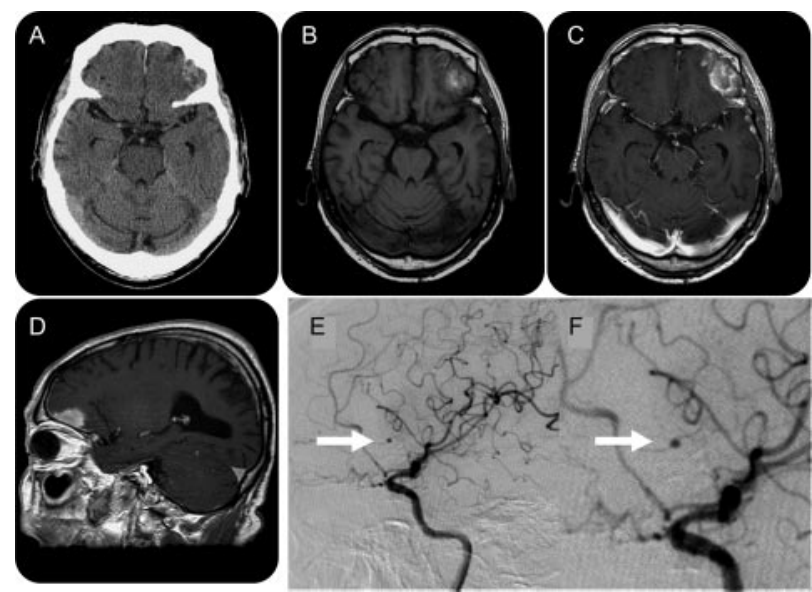

Nonenhanced axial CT (A) and MRI with axial nonenhanced (B), axial enhanced (C), and sagittal enhanced (D) T1-weighted imaging demonstrates an extra-axial, contrast-enhancing lesion in the left anterior fossa. $(E, F)$ Lateral view of the left internal carotid angiogram reveals a peripheral middle cerebral artery aneurysm.

Figure 2 Surgical images

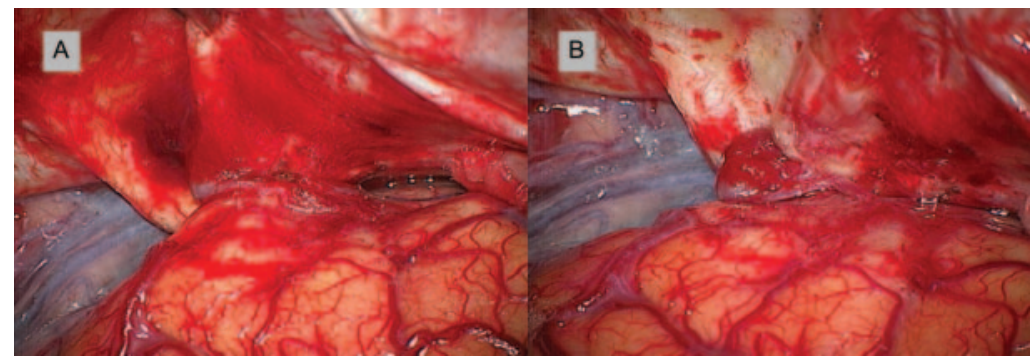

Intraoperative view confirming acute and subacute subdural hematoma (A) and documenting a small peripheral middle cerebral artery aneurysm attaching to dura mater after removal of the surrounding hematoma (B).
A 75-year-old man with no history of head trauma presented with a 10-day episode of left forehead heaviness followed by sudden headache and vomiting. Neurologic examinations were unremarkable. Neuroimaging showed left frontal extra-axial lesion suggestive of acute and subacute subdural hematoma (figure 1, A-D). CSF analysis revealed normal cytology and the absence of xanthochromia. An angiogram demonstrated peripheral left middle cerebral artery aneurysm (figure 1, E and F). No echocardiographic or serologic evidence of infectious endocarditis was noted. Craniotomy confirmed cerebral aneurysm surrounded by subdural hematoma (figure 2). After resection, histologic examination documented a ruptured true aneurysm.

Intracranial aneurysm is infrequent in peripheral cerebral artery ${ }^{1}$ and a probable cause is infectious endocarditis. The possibility of peripheral cerebral aneurysm rupture should be considered in spontaneous subdural hematoma even with no evidence of subarachnoid hemorrhage. ${ }^{2}$

\section{S. Kurabe, MD, T. Ozawa, MD, PhD, \\ H. Fujiwara, MD, T. Watanabe, MD, PhD, \\ T. Aiba, MD, PhD, Niigata, Japan}

Disclosure: The authors report no disclosures.

Address correspondence and reprint requests to Dr. Satoshi Kurabe, Department of Neurosurgery, Niigata Prefectural Shibata Hospital, 1-2-8 Honcho, Shibata, Niigata, 957-8588, Japan; skurabe@bri.niigata-u.ac.jp

1. Nussbaum ES, Madison MT, Goddard JK, Lassig JP, Nussbaum LA. Peripheral intracranial aneurysms: management challenges in 60 consecutive cases. J Neurosurg 2009;110:7-13.

2. Bassett RC, Lemmem LJ. Subdural hematoma associated with bleeding intracranial aneurysm. J Neurosurg 1952; 54:443-450. 


\section{Neurology}

\section{Peripheral intracranial aneurysm causing subdural hematoma without subarachnoid hemorrhage}

S. Kurabe, T. Ozawa, H. Fujiwara, et al.

Neurology 2010;74;268

DOI 10.1212/WNL.0b013e3181ca011c

\section{This information is current as of January 18, 2010}

\section{Updated Information \&} Services

References

Subspecialty Collections

Permissions \& Licensing

Reprints including high resolution figures, can be found at: http://n.neurology.org/content/74/3/268.full

This article cites 2 articles, 0 of which you can access for free at: http://n.neurology.org/content/74/3/268.full\#ref-list-1

This article, along with others on similar topics, appears in the following collection(s):

CT

http://n.neurology.org/cgi/collection/ct

MRI

http://n.neurology.org/cgi/collection/mri

Other cerebrovascular disease/ Stroke

http://n.neurology.org/cgi/collection/other_cerebrovascular_disease_st roke

Secondary headache disorders

http://n.neurology.org/cgi/collection/secondary_headache_disorders

Information about reproducing this article in parts (figures,tables) or in its entirety can be found online at:

http://www.neurology.org/about/about_the_journal\#permissions

Information about ordering reprints can be found online:

http://n.neurology.org/subscribers/advertise

Neurology ${ }^{\circledR}$ is the official journal of the American Academy of Neurology. Published continuously since 1951, it is now a weekly with 48 issues per year. Copyright . All rights reserved. Print ISSN: 0028-3878. Online ISSN: 1526-632X.

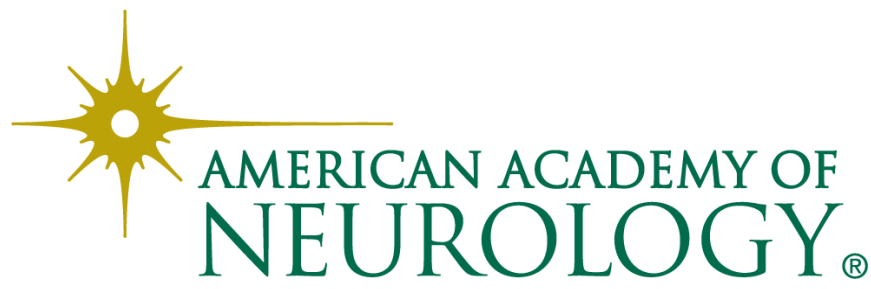

